43-44 | 2013

Le pastoralisme en Haute-Asie : la raison nomade dans l'étau des modernisations

The yak, an essential element of the high altitude regions of Central Asia

Le yak, un élément essentiel des régions de haute altitude d'Asie centrale

\title{
Gerald Wiener
}

\section{(2) OpenEdition}

\section{Journals}

Electronic version

URL: https://journals.openedition.org/emscat/2038

DOI: $10.4000 /$ emscat.2038

ISSN: 2101-0013

\section{Publisher}

Centre d'Etudes Mongoles \& Sibériennes / École Pratique des Hautes Études

Electronic reference

Gerald Wiener, "The yak, an essential element of the high altitude regions of Central Asia", Études mongoles et sibériennes, centrasiatiques et tibétaines [Online], 43-44 | 2013, Online since 20 September 2013, connection on 13 July 2021. URL: http://journals.openedition.org/emscat/2038 ; DOI: https:// doi.org/10.4000/emscat.2038

This text was automatically generated on 13 July 2021.

(c) Tous droits réservés 


\title{
The yak, an essential element of the high altitude regions of Central Asia
}

\author{
Le yak, un élément essentiel des régions de haute altitude d'Asie centrale
}

\section{Gerald Wiener}

1 The yak is critical for the life and economic activity of the people on the vast and inhospitable Qinghai-Tibetan plateau and in the surrounding mountainous areas. The late Professor Cai Li went so far as to suggest that without the yak no civilisation would have developed in this region (personal communication; Cai Li was a distinguished scholar at the South-west University of Nationalities who had dedicated himself to the lifelong study of the yak and the role of the yak in the life of the people).

2 This article is intended to provide a brief overview of the yak's distribution and management, its attributes and what makes it "special" for the vast mountain regions and high plateaux of Western China and the adjoining territories to the south and north. As it is intended, especially for those not very familiar with the yak, to provide a background about the animal which links together all the other papers in this issue, this article will end with a very brief speculation about the future.

3 From very earliest times the yak has been intimately associated with the culture, religion and social life of the herders and their families. Moreover, no discussion of yak keeping can be divorced from the constraints imposed by the environment and the available grazing lands. No discussion of future opportunities for improving productivity should be conducted in separate compartments of animal, environment, grazing land, social context and economic constraints. Any discussion and action based on it should have regard to the multi-disciplinary nature of the problem.

4 The yak was classified by Linnaeus in 1766 as Bos grunniens but more recent evidence favours Poephagus grunniens. Wild yak and domestic yak represent two distinct populations. While wild yak are close to being an endangered species, domestic yak number in the order of 13 to 14 million - the vast majority them in China, where there does not appear to have been the same marked decline in yak numbers noted in peripheral countries. 
Zeuner (1963) suggested that the yak was first domesticated by the ancient Qiang people in the late Stone Age around ten thousand years ago - a view widely accepted by other authors and argued from historical documents (see Wiener, Han \& Long 2003). More recent evidence based on a combination of fossil evidence and mitochondrial DNA studies suggests that domestication may not have taken place until about five thousand years ago (Xue-bin Qi et al. 2008). But whatever the exact period when this occurred, the yak alone was capable of meeting all the needs for human survival - though sheep and goats had been domesticated earlier. The yak was valued as a beast of burden but also provided meat, milk, hide, wool and hair and, of paramount importance, its dung for fuel in a tree-less landscape - all basic necessities for life. Thus, as Cai Li had remarked, a civilisation was able to develop against the odds at high altitude in a hostile climate. Eventually the distribution of the yak expanded outward. The route of this expansion was recently studied with the help of molecular genetic data (Xue-bin Qi et al. 2008). It suggests that the eastern part of the Qinghai-Tibetan Plateau could be the centre of yak domestication with two separate dispersal routes, one westward into the "Pamir Knot" by passing through the Himalayan and Kunlun Mountains and the other northward into Mongolia and Russia by passing through the Gobi Desert and Altai Mountains.

6 From its very beginnings, the domesticated yak, descended from the wild yak, made not only the most important contribution to the livelihood of the herders and their families but was also involved in their culture, religion and social life.

7 The economically most important aspects of the yak's fitness traits and the productive and reproductive attributes of the yak will now be briefly summarised. Fuller descriptions and details can be found in Wiener, Han and Long (2003).

\section{Breeds and breeding}

8 Some twelve or so different breeds of yak are recognized in China. They appear to differ both in looks (colour, etc.) and in aspects of performance. However, most of these "breeds" are restricted to particular localities so that in terms of their performance any genetic differences are confounded with the environment in which they are kept. Recent techniques of molecular genetics have however started to show some degree of genetic distance between the yak populations (Xue-bin Qi et al. 2005, Zhang G.X. et al. 2008). In countries outside China yaks are generally named after the territory in which they are found.

9 Yak can be hybridized with cattle. Cross-breeding was commonplace in areas where the distributions of yak and local cattle adjoined or overlapped, and is reported to have occurred for the past 3000 years. As recorded in more recent times (but probably noted even in ancient times) the hybrids appear to have many of the fitness characteristics of the yak and the better productivity of the cattle. Hybrid males are, however, sterile and hence the F1 type cannot be fixed (hybrid females can, however, be backcrossed - see below). The hybrids are especially favoured at the lower elevations of yak distribution, where better feed is available.

Hybridisation of yak females with "exotic" breeds of cattle started in China around 1939. Cai and Wiener (1995) write: "Since around 1939 in China, starting at Datong in Qinghai province, and from 1941 in the area now known as the Ganzi Tibetan 
autonomous prefecture in Sichuan, some yak were 'crossed' (hybridised) with Dutch Holstein Friesian bulls. Such 'crossing' did not, however, become systematic until the mid-1950's when 200 bulls of various breeds were introduced to the yakproducing areas of China. The breeds included the Holstein Friesian, Shorthorn, Simmental, etc. More recently, Charolais, Hereford, Limousin and others have been added to those available for 'crossing' with yak"1. Hybridising was tried initially by natural mating, but over the first twenty years barely 1000 F1 animals were produced compared with about 32000 between 1979 and 1985. During that latter period, artificial insemination (AI) with exotic bull semen became the predominant practice for hybridising.

11 Hybridisation of yak with exotic cattle has been encouraged by the officialdom on the strength of the better growth rates and much higher milk production of these "exotic" hybrids relative to the yak. The extra production has, however, to be paid for by better feeding, provision of shelter and better all-round management and health care. Moreover the difficulties of detecting oestrus in yak females - essential as a prelude to the use of AI - as well as the fact that relatively few yak localities have access to AI, restricts the opportunities for this form of hybridisation. Its advantages may be more apparent than real. It should also be noted that the replacement rate of the purebred yak herd (or population) sets a strict limit on the extent to which hybrid calves can be produced.

12 It is of interest to note that Xue-bin Qi et al. (2009) have studied the extent of introgression of taurine and zebu genes into the yak population using mitochondrial and microsatellite DNA markers. Such introgression is made possible by the fact that after 4 or 5 generations of backcrossing of the F1 cows and the subsequent backcross generations to yak bulls, male fertility is restored to the bulls that are then, for all practical purposes, indistinguishable from pure yak. The authors find significant numbers of introgression cases (though the level of genomic admixture is still very low among the yak populations) but it is unclear how much or little of the introgression relates to European-type cattle breeds. The authors do, however, make the point that they could not differentiate between the use of popular "exotic" cattle breeds like the Holstein-Friesian derived from those already extant in China and those directly imported as live animals or as semen from abroad.

13 Crossing of domestic yak with wild yak occurred naturally over the centuries in areas where wild yak territory bounded on domestic yak herds. The cross was recognised as being more vigorous and larger than the domestic yak. In recent times these advantages have been re-created by using semen from captured wild yak bulls on domestic yak females. Amongst others, this has led to the creation of the Datong breed built on several generations of selection starting from the initial cross.

\section{The environment}

14 Elevations of between 1000 and $4500 \mathrm{~m}$ are typical of the yak environment - with the lower elevations at the most northerly latitudes. On the Qinghai-Tibetan Plateau elevations above $3000 \mathrm{~m}$ are normal. In this cold and harsh climate growing seasons for vegetation are short at around 100 days - followed by 3 to 4 months when wilted herbage provides a decreasing supply of feed which can, however, be near-adequate for the animal's maintenance. From late winter to early spring feed shortage and variable snow cover lead inevitably to severe malnutrition and weight loss of the animals - by 
about $25 \%$ in cows. In recent times winter feeding has been increasingly advocated but is practicable mostly where crop growing areas are within reach. However, new developments in plant breeding are likely to result in new varieties of forage crops tolerating the very short growing seasons. These developments from plant breeding may further benefit the winter feeding situation. There is little doubt that access to winter feed reduces weight loss in cows and can lead to a significant improvement in reproductive and productive capacity including calf survival and growth.

Climate and topography determine soil types and the vegetation of the rangelands. Extremes range from desert steppe (rainfall around $50 \mathrm{~mm}$ per year) with Ceratoides spp. predominant. In intermediate rainfall situations (ca. $200 \mathrm{~mm}$ ) are areas of alpine steppe (Stipa spp.predominating among grasses). Whilst in areas of highest precipitation (up to $600 \mathrm{~mm}$ per year), alpine meadows support sedges, low shrubs and other vegetation. These factors influence stocking densities and the relative importance of yak to sheep and goats in the grazing and management system.

\section{Management considerations}

Management is dictated by the pastoral landscape, the seasons, climate, topography as well as social-cultural factors. The resultant transhumance system of herding involved migrations of yak herds starting in the spring to reach high summer pastures followed by a slow return in the autumn to the winter pastures and the more permanent settlements of the herders.

During summer and early autumn, when herds were grazing at the higher elevations, the herders traditionally lived in campsites and moved as often as necessary depending on the availability of grazing. During winter and early spring the yak were kept at lower elevations nearer to the permanent homes of the herders. Increasingly, shelters are provided especially for calves to protect them against the worst extremes of the weather.

Formerly, the animals of several families were herded together. Milking females and their calves were kept separate from younger females and from males. Now, in China, some of these communal systems of transhumance management are breaking down under a policy of "Household Responsibility". This policy provides for individual ownership of the animals and rights (though not ownership) to parcels of rangeland some of which is being fenced. This has potentially profound effects on management. As the number of yak owned is also considered a form of insurance against natural disasters and hard times, there must be a temptation to increase numbers above the natural carrying capacity of the pastures. Thus, overgrazing has become increasingly recognised as a problem. Fencing, moreover, is likely to inhibit the free movement of herds and may well restrict the freedom of herders to exploit the availability of grazing to best advantage. These developments have clear social implications and provide an incentive for more permanent settlement of the herders and their families. But in terms of utilising the natural resources of the rangeland it has yet to be shown whether the new system is as effective as the old.

The natural vegetation is almost the only feed available for the yak - summer and winter. Summer is a time of plenty. The animals gain weight rapidly after severe weight loss over winter and early spring (as referred to above, a loss of 25-30 percent in 
liveweight is not uncommon). During that time, animals can be close to starvation and deaths are common - especially in years of heavy snow. Supplementary feeds, such as hay or crop by-products, have not generally been available except in very small quantities, and mostly for weak animals. However this, as already discussed, may now be changing.

The critical association of yak herding with the availability of grazing was and remains of paramount importance to the economic success or failure of a system which is thought to have survived almost unchanged until the most recent times. The topic of rangeland management in modern terms draws attention to the dangers of overgrazing and the fragile nature of the ecosystem. Some of the articles in this issue of the journal take this matter further.

Economically the most important aspects of the yak's productive and reproductive and fitness traits will now be briefly summarised ${ }^{2}$.

\section{Production and Products}


28 Nepal is the only country at present, among those rearing yak, with an established industry based on converting milk from yak and yak hybrids into a Gruyère-type cheese in cheese factories. Because of the interest that this has generated in some neighbouring countries as a potential model to adopt, it may be useful to provide some details of the process. An essential feature is that a factory should be within reasonable walking distance for the herders who supply the milk. The buildings can vary in construction ${ }^{4}$ but access to fuel and water are needed as is a supply of electricity, which can be generated locally. According to Joshi et al. (1999) the production of a Swiss-style (Gruyère-type) cheese developed in Nepal, based on Swiss technology, from the 1950s onward. At the time of writing Joshi et al. (1999) noted that there were 11 cheese factories run by the Nepalese Dairy Development Corporation (DDC) and a number of privately-run cottage factories producing, in 1998/99, 150 metric tonnes of "yak cheese" from yak and hybrid yak milk (out of a total cheese production of 350 metric tonnes). Privately-run cheese factories - compared to those controlled by the DDC generally entailed a lower investment in the infrastructure, equipment and processing refinements required, and consequently the quality of the cheese produced by them was often markedly inferior ${ }^{5}$. Since the time that the Joshi et al. (1999) report was written there has been a decline in the number of yak and hybrid yak ${ }^{6}$. It would not be surprising, however, if some of the production capacity has not been diverted to milk from other species, buffalo in particular.

29 Joshi et al. (1999) record that 10 litres of milk from yak or yak hybrids produce $1 \mathrm{~kg}$ of cheese. The 16-stage process includes standardising the fat content of the milk, pasteurising, adding culture and rennet, curd formation and cooking followed by moulding and pressing. The cheese blocks are brined and stored for ripening. After 5 months of ripening a good flavour develops ${ }^{7}$. An assessment of the economics involved concluded that, at that time, demand for the yak cheese outstripped supply, that more investment was needed as well as rehabilitation of some of the factories and improvement in the production chain from farm to marketing. Of the four factories studied in detail, three were in profit, with income exceeding costs, but one was running into deficit. Virtually all the yak cheese production was purchased by tourists to Nepal and not consumed by the herders. This suggests that production of this Gruyère-type cheese would find a place in other yak-rearing countries only if tourism prevails or export potential can be realised.

Meat is derived from cull cows and more importantly from castrate males. These steers are rarely slaughtered before the age of 4 years old and possibly older. Payment has traditionally been based on size ("weight") and older animals thus have an advantage. However, by the age of 4 or 5 years the individuals have been through several cycles of weight gain and weight loss. This is intrinsically inefficient. In herds with high stocking densities and where there is a prospect of overgrazing it might be more sensible to slaughter castrate males a year or two earlier and keep in their place extra young females. It may even be that the market could be persuaded to pay a higher unit price for the younger animals with an expected better meat quality. Tradition of course is difficult to shift.

31 Meat when not sold but kept for the consumption of the herders and their families is stored in either dried or frozen form or smoked, and different types of sausages and other meat products are manufactured. The blood finds its way into sausage-type 
products. Inedible parts, regarded as offal, are discarded on the grasslands and can create pollution if not taken by birds of prey.

The fleece is made into blankets and down wool into garments. The potential of the cashmere-like quality of the down fibres has not been adequately exploited in international markets where such garments command a high price.

The hide when tanned is made into the usual leather products but also into ropes used for crossing streams and rivers and into coracles to carry goods on water. Pelts, mostly from the hides of calves that have died, find a use made into coats for children.

Arguably one of the most important products from the yak is its dung which, when dried, represents the main source of fuel in a treeless landscape.

\section{Reproduction}

In China, a majority of female yak do not come into oestrus for the first time until two years old and calve first at the age of four years. One calf every two years is the norm but two calves in three years is not uncommon. This relatively slow reproductive rate is the result of inadequate feed for maintenance and frequent near-starvation, with consequent severe weight loss over winter and especially in early spring. Cows that happen to be pregnant over that stressful time then need a year to recover body condition sufficiently to become pregnant again. Where good conditions of winter feeding prevail (as for example in the yak herds established in the USA) yak calve earlier for the first time (at two or three years old) and do so annually thereafter.

The peak months for mating are August and September. Average gestation length is 258 days. Over a lifetime, yak cows will have four or five calves. Traditionally, bulls running in groups fought for possession of females at mating, but this is gradually being superseded by deliberate allocation of bulls to herds.

\section{The special adaptive attributes of the yak}

What makes the yak special for the environment in which it predominantly lives? The yak has adapted to cold, to low oxygen at high altitudes, to shortage of feed for up to seven months of the year, to precipitous terrain and danger from predators (primarily wolves).

Heat is conserved through a compact body, a covering of thick outer hair and a fine down undercoat in winter. The yak's resistance to cold is aided by a compact body with short neck and short limbs, short tail, small ears and no dewlap. The scrotum in the male and the udder in the female are small and hairy. The surface area of the yak is relatively small per unit area of bodyweight and the yak has few sweat glands. The yak also has a thick skin with non-functioning sweat glands and by autumn a significant layer of subcutaneous fat. Oxygen uptake is aided by large lungs and heart, rapid breathing and haemoglobin with a high affinity for oxygen uptake. Yak can graze diverse vegetation from coarse shrubs to short grass. They do this by grazing short herbage in the manner of sheep and the taller, rougher herbage in the manner of cattle. Moreover, yak can adjust their bite rate according to the available forage biting more quickly in winter and spring and more slowly in summer. Relative to indigenous cattle, the yak appear to have a lower rate of urinary nitrogen excretion (an 
adaptation to poor feed supply) and also a better efficiency of nitrogen utilization in part due to greater microbial protein production in the rumen. This is thought to assist in the recovery of body weight over the summer grazing period (Wang et al. 2009). The yak's hoof shape makes them surefooted in often treacherous terrain - a capacity that made them an ideal beast of burden. As protection against predators yak have an instinct to group into tight herds (Ding et al. 2008) in the face of danger.

\section{Concluding thoughts}

Yak production is most profoundly affected by the environment and economic returns by marketing structures - or their absence. Whilst the environment of the yak territories cannot be changed, some of its worst effects may be ameliorated by provision of shelter in winter, provision of supplementary feed, improved management including the avoidance of overgrazing, and provision of health care. For any of these action to be worthwhile requires an adequate economic return for the herders. Good marketing structures are therefore an important component but have often been inadequate in the past. Social change, driven by settlement of herders' communities, provision of roads allowing access to more distant markets and educational opportunities may change yak production from a largely subsistence activity for family units to a market-driven one. In countries peripheral to China, yak populations are in decline as a younger generation of men and women are no longer as willing as their parents to endure the harshness of traditional yak herding. Moreover, the factors which may convert yak production from subsistence to market driven are also the factors which attract the young to a notionally better life in towns and cities. This problem is not specific to yak herding but is a commonplace experience in many, perhaps most, rural agricultural communities. Sons with different aspirations and experiences from those of their fathers no longer follow automatically in the footsteps of their elders. Clearly this has long-term implications for the future of yak herding. Social changes in the rural population driven from within or imposed from above will eventually determine the future of yak herding even in the regions of China most suited to it. In those circumstances is there a future for the yak?

While a harsh way of life with poor economic returns cannot or should not be imposed on a people, it remains a fact that the yak along with sheep and goats do provide a useful exploitation of the natural resources of the rangelands. The rapidly expanding human population of the world and the consequent need to expand food production makes it irrational to allow the vast yak territories to be turned merely into an unexploited wilderness - in spite of potential benefits for wildlife and tourism. A more likely scenario might be for large herds of yak to be minimally managed in a ranchingstyle production system with meat as the principal product. By the same token, the very particular adaptation of the yak to harsh conditions coupled to a need to feed an ever-increasing human population may yet make the yak a suitable contributor to world food needs in some as yet unexploited but inhospitable parts of the world.

41 To improve economic returns from yak in the more immediate future, possibilities exist for developing niche markets in distant cities or other countries for some of the yak products. Recent attempts to do so for milk and meat products have not yet lived up to expectations of the companies concerned. However, an obvious example for a more restricted but high value market is production of the cashmere-like garments 
manufactured from the high-quality yak down that command high prices in Europe and North America. But even this obvious opening is not adequately exploited by the yak fraternity. Medicinal products such as bezoar, produced by inoculation of the gall bladder, and ornamental products from horn, bone and hair have the potential to provide add-on value for yak herders but the marketing opportunities are apparently not well organised.

42 Another aspect affecting both the present and future of yak production is the relevance of research support and extension work for the yak industry. Much research with yak is conducted at a large number of universities and institutions in China and neighbouring countries. But it should be asked how much of this effort makes a worthwhile contribution to the actual improvement of yak productivity. One reason for pessimism is that much research deals with minutiae which can be neatly and quickly published and hence attract the notice and approbation of funding bodies but which, in the case of yak, do not address the wider problems of yak production. These require a multidisciplinary and integrated approach which is altogether more complex and longterm, and hence more difficult to achieve and to judge. Nonetheless research into feeding systems and feed utilisation, rangeland management, disease control and marketing structures conducted in often very specific situations has the potential for useful wider application if promoted by good extension services.

Genetic research is now largely in the hands of DNA experts, providing no more than a promise of some practical reward for yak breeding in a distant future. Again, however, it would be foolish to discount the possibility that advances in genetic knowledge in cattle elsewhere - for example, the discovery of quantitative trait loci - may not find their counterpart in yak and then become a tool in genetic selection.

A final thought concerns the as yet unpredictable effects of climate change on the ecosystem. Effects of climate change on the Himalayas with consequences for water supplies and rain patterns are already being documented. Consequences for animal production on the high rangelands are still entirely speculative but must be part of the considerations for the future.

\section{BIBLIOGRAPHY}

Cai, Li \& Wiener, G.

1995 The yak (first edition) (Bangkok, Food and Agriculture Organisation of the United Nations), $237 \mathrm{p}$.

Ding, L. M., Long, R. J., Shang, Z. H., Wang, C. T., Yang, Y. H., Xu, S. H.

2008 Feeding behaviour of yaks on spring, transitional, summer and winter pasture in the alpine region of the Qinghai-Tibetan plateau, Applied Animal Behaviour Science 111, pp. 373-390.

Joshi, D. D., Awasthi, B. D. \& Sharma Minu

1999 An assessment of the yak cheese factories in Nepal, National Zoonoses and Food Hygiene

(Kathmandu, Research Center Publ.), 75p.

Études mongoles et sibériennes, centrasiatiques et tibétaines, 43-44 | 2013 
Thapa, T. B.

1996 Yak cheese production in Nepal, in D. G. Miller, S. R. Craig and G. M. Rana (eds.) Proceedings of a Workshop on Conservation and Management of Yak Genetic Diversity at ICIMOD, Kathmandu, 29-31 October 1996 (Kathmandu, ICIMOD (International Centre for Integrated Mountain Development), pp. 165-171.

Wang, H. C., Long, R. J., Zhou, W., Li X. P., Zhou, J. W., Guo, X. S.

2009 A comparative study on urinary purine derivative excretion of yak (Bos grunniens), cattle (Bos taurus), and crossbred (Bos taurus x Bos grunniens) in the Qinghai-Tibetan plateau, China Journal of Animal Science 87, pp. 2355-2362.

Wiener, G., Han Jianlin \& Long Ruijun (eds.)

2003 The yak (second edition) (Bangkok, Food and Agriculture Organisation of the United Nations), $460 \mathrm{p}$.

Xue-bin Qi, Han, J., Lkhagva, B., Chekarova, I., Badamdorj, D., Rege, J. E. O., Hanotte, O.

2005 Genetic diversity and differentiation of Mongolian and Russian yak populations, J. Anim.

Breed. Genet. 122, pp. 117-126.

Xue-bin Qi, X. B., Han, J., Blench, R., Rege, J. E. O., Hanotte, O.

2008 Understanding yak pastoralism in Central Asian Highlands, in A. Sanchez-Mazas, R. Blench, M. D. Ross, I. Peiros, M. Lin (eds.) Past Human Migrations in East Asia : mitochondrial DNA evidence for origin, domestication and dispersal of domestic yak (Chapter 20) (Routledge : Abingdon, Oxon U.K., 2008), pp. 427-442.

Xue-bin Qi, Han Jianlin, Wang, G., Rege, J. E. O. \& Hanotte, O.

2009 Assessment of cattle genetic introgression into domestic yak populations using mitochondrial and microsatellite DNA markers, Animal Genetics 41, pp. 242-252. doi :10.1111/j.

1365-2052.2009.01989.x

Zhang, G. X., Chen, W. S., Xue, M., Wang, Z. G., Chang, H., Han, X., Liao, X. J., Wang, D. L. 2008 Analysis of genetic diversity and population structure of Chinese yak breeds (Bos grunniens) using microsatellite markers, J. Genet. Genomics 35, pp. 233-238.

\section{NOTES}

1. The same information can also be found in Wiener, Han \& Long 2003. The Angus breed appears to have been omitted from that list, while some other taurine cattle breeds, not quoted above, were used in other countries.

2. Fuller descriptions and details can be found in Wiener, Han \& Long 2003.

3. Details of these products and how they are made can be found in Wiener, Han \& Long 2003.

4. In their booklet Joshi et al. (1999) give an illustration of a "mobile" structure little more than a large shack.

5. This is essentially a "historical" assessment as no very recent records are available.

6. The current quantity of cheese production is not known.

7. For details see Thapa 1996. 


\section{ABSTRACTS}

The yak is critical for the life and economic activity of the people on the vast and inhospitable Qinghai-Tibetan plateau and on the surrounding mountainous areas. This article gives an overview of the domestication, the geographical distribution, the herding practices, the production and the products of the yak. Its breeding and hybridization management, as well as its reproduction and its special adaptation attributes are reviewed. Concluding thoughts about the role of the research and the role of social changes - driven from within or imposed from above - on the future of yak production systems are outlined.

Cet article présente une vue d'ensemble de l'élevage du yak. Cet animal joue un rôle central dans la vie et l'activité économique sur les hauts plateaux inhospitaliers du Qinghai-Tibet et dans les massifs montagneux environnants. L'article présente les principales caractéristiques de la distribution géographique du yak, de son élevage, de son adaptation à cet environnement si difficile et de ses productions, ainsi que de sa reproduction et de son hybridation. L'auteur développe ensuite quelques réflexions sur les enjeux de recherche et sur le rôle que peuvent avoir les changements sociaux qui s'annoncent dans ces territoires d'altitude sur le devenir des systèmes d'élevage.

\section{INDEX}

nomsmotscles Tibetans

Geographical index: China, Himalaya, Mongolia, Tibet

Keywords: highlands ecosystems, hybrids, livestock systems, yak

\section{AUTHOR}

\section{GERALD WIENER}

Gerald Wiener, BSc, PhD, DSc, FRSE, FSB, CIBiol, is a British senior scientist in animal breeding and physiological genetics. Former Head of the Department of Physiological Genetics and Deputy Director of the Agricultural Research Council's Animal Breeding Research Organisation (now the Roslin Institute, Edinburgh), he is the author of many scientific papers and of the book "Animal Breeding" published by Macmillan (and translated into Chinese and French); he is also contributor to several other books.

Honorary member of the British Society of Animal Science, he worked as senior editor (for some 25 years) of "Animal Production" (later "Animal Science") the Journal of the British Society of Animal Science.

Dr. Gerald Wiener was called for consultancies with FAO and the British Council, and especially in China (more than 3 years). He was Honorary Professor at the Agricultural University of Gansu and at the South-west University for Nationalities in Chengdu (China). He is the senior co-author of the book "The Yak" published by FAO (first edition 1995, second edition 2003).

wiener@biggarview.demon.co.uk 